\title{
Implementation of Moderate Islamic Curriculum in the Establishment of Student Character
}

\author{
Akhmad Shunhaji ${ }^{1^{*}} \quad$ Febriany Lestari $^{2}$ \\ 1.Lecturer at the PTIQ Jakarta Institute \\ 2.Teacher at SD Syafana Islamic School, Tangerang
}

\begin{abstract}
The religious life of people in Indonesia, especially in religious life, has received the spotlight from various parties, both from within and outside the country. This is inseparable from the emergence of social conflicts with religious backgrounds in society. Starting from cases of religious blasphemy, destruction of houses of worship, hate speech on social media and mutual discredit between one people and another and people who are of the same faith. This research methodology is qualitative with a case study of Moderate Islamic Curriculum Implementation at SD Syafana Islamic School aims to describe: (1) Moderate Islamic curriculum implementation; (2) Implementation of the hidden Curriculum; and (3) The effectiveness of the moderate Islamic curriculum.From the results of interviews, questionnaires and analysis of the research documents, the results are as follows. (1) The moderate Islamic curriculum at SD Syafana School is implemented according to plan because it is supported by teachers and education personnel as well as available sarpras. The teachers are trained first before carrying out the lesson. (2) Likewise, the hidden curriculum can be applied through various activities outside of subject learning, but through school activities, such as several competitions, tahfish, and so on. (3) The Moderate Islamic Curriculum at SD Syafana School goes according to plan, provides knowledge, fosters attitudes and behavior as students who have character and tolerance among fellow students and are able to avoid actions and speech that are inappropriate or not praiseworthy, including bulyying for Muslim students. Thanks to the guidance and support of teachers and education staff, the implementation of the Moderate Islamic Curriculum has been effective.In conclusion, the application of the Hidden Curriculum at SD Syafana Islamic School has an impact in the form of understanding, tolerant attitudes and behavior towards diversity, differences of opinion, views, avoiding hate speech and bullying and still associating with empathy and mutual respect as a reflection of the character of students.
\end{abstract}

Keywords: Curriculum Implementation, Moderate Islam, Character Education

DOI: $10.7176 / \mathrm{JEP} / 11-36-04$

Publication date: December $31^{\text {st }} 2020$

\section{A. Profile of SD Syafana Islamic School}

Syafana Islamic School is a flagship school, which organizes Islamic education at national and international standards, founded in 2005, at Gading Serpong Resident, Tangerang. Graduates of this school are expected to become true believers, future leaders with higher academic skills, so that they are able to enter top national and international universities.

In particular, the Syafana school produces students who have life competencies that are integrated with Islamic values and are ready to follow the next superior education level. Implementation of moderate Islam and its curriculum Hidden curriculum support and in line with the concept of moderate Islamic in SD Syafana Islamic School. The concept of moderate Islam is basically as explained by the clerical figures, among them, according to Yusuf Al-Qardhawi, as follows. Moderate Islam is more in the meaning of the language, namely as "midposition between liberalism and Islamism". People or organizations that are in the middle between liberalism and Islamism are moderate Yusuf Al-Qardhawi declared moderate Islam as altawazun (balance), which is a balance between two roads or two directions that are opposite or contradictory: ruhiyah (spiritualism) and maddiyah (materialism) ); fardiyah (individual) with jamaiyah (collective); waqi "eiyah (contextual) with mitsaliyah (idealism); tsabat (consistent) with taghayyur (change). Therefore, the balance (al-tawazun) continued AlQardhawi; in fact, it is the nature of the universe as well as the character of Islam as an eternal treatise. In fact, according to Islam, charity has pious values, if the charity is placed in the principles of balance between hablun minallah and hablun minannaas.

According to the Chairman of the foundation SD Syafana, meaning vision berid e ologi moderate Islam Islamic School Syafana intends Washatiyyah (moderation) of Islam in Indonesia, since 14 years ago when it set up the foundation. The first step is to formulate a vision, mission, goals, targets, way, curriculum and so on. Of the many points formulated earlier and in depth, among them are related to the curriculum and hidden curriculum which is the concern of researchers. The way Syafana is Ahlusunnah Wal Jamaah Asy'aryah Syafiiyah who is oriented towards Al-Azhar Assyarif in Cairo - Egypt which has been known for thousands of years as a center of Islamic education and culture.

The concept of Washatiyyah Islam is understood, reflecting the principles of tawassut (middle), tasamuh (tolerant), tawazun (balanced), i'tidal (fair), iqtisad (simple). Thus, the term Ummatan Wasatan is 
often referred to as a just people or "a just community; namely the community or community that displays the above criteria . Islam has many characteristics, as a religion of compassion and peace (din-ar-rahmah wa as-salamah), a religion of justice (din al-adl), a religion of progress (din al-hadharah), and even explicitly the Koran mentions Islam as Ummatan Wasathan, a moderate Ummah.

And that the solution to challenges in the Indonesian state, according to the head of the foundation at SD Syafana Islamic School, for the 21st century the application of the Moderate Islamic curriculum is very important and becomes a solution to the problems and challenges of the nation and state of the Republic of Indonesia.

\section{B. Implementation of Moderate Islamic Curriculum at SD Syafana Islamic School. \\ 1. Curriculum planning}

Syafana Islamic School has a vision to become a reference school in Indonesia as a foundation for building a civilized generation. Meanwhile, the mission carried out by this school is to form students who have strong moral traits, have noble character, are broad-minded, intelligent, healthy, independent, creative and have leadership spirit. In general, the translation of the vision and mission to shape a generation of quality which has the following characteristics: (1) belief, (2) True worship, (3) Good behavior, (4) Broad horizons, (5) Strong physical, (6) Strict time keeping, (7) Discipline at work, (8) Professional in their fields, (9) Independent, and (10) Beneficial for others .

In particular, this school wants to produce students who have life competencies that are integrated with the I slam values and are ready to follow the superior education level, then besides that also by referring to the principles of school learning

Making students the center of potential development to prepare themselves for the glory of their time (the principle of "student-centered learning"). Accommodating uniqueness of students through student-centered learning programs (the principle of multiple intelligence) Developing social skills in the form of cooperative learning, working in groups, learning collaboration and debate (the principle of " learning to know, to do, to be, to live together ) by using an integrated approach between religious knowledge, character and science (integrated curriculum principles ).

Develop good and quality communication skills using Indonesian, English, Arabic (the principle of "three languages"). Syafana Islamic School has a vision to become a reference school in Indonesia as a foundation for building a civilized generation. Meanwhile, the mission carried out by this school is to form students who have strong, noble, broad-minded, intelligent, healthy, independent, creative and leaderminded students, make Syafana Islamic School a reference school and build Syafana Islamic School throughout Indonesia .

Syafana Islamic School has a noble mission to ground Islamic washatiyyah, namely:

1) all the academic community of Syafana Islamic School can understand that the commandment of da'wah in Islam aims at the realization of transformations and changes to goodness and truth, both at the personal level and in an elegant society, which is done persuasively and communicatively, not blind indoctrination

2) Syafana Islamic School must show that Islam is a religion of rahmatan lil alamin, loves peace and prohibits violence.

3) Syafana Islamic School must interpret Islam in a flexible textual level, able to read the realities of life and reject extremism in the form of injustice and falsehood.

4) Syafana Islamic School must cultivate the character of its students who are religious, humanist, nationalist, democratic and prioritize the people's welfare, and most importantly uphold good morals, character, identity and integrity as khairu ummah in life, humanity and civilization.

The implementation of the curriculum and hidden curriculum is translated into a number of lessons and activities such as: school habits of applying discipline to students, routine school activities, the accuracy of teachers starting lessons, the ability of teachers in class management, reward and punishment, an orderly, neat school environment. , as well as communication patterns between school stakeholders. All of these are experiences that have an impact on influencing students' thinking, behavior and culture.

Researchers will explain the design and implementation of moderate Islamic curriculum along with hidden curriculum in supporting moderate Islam at SD Syafana Islamic School. That the stages of school planning are based on the vision and mission of the school, with the vision of making the school breathe I slam, leading and having an international perspective. As well as the mission to develop faithbased education, noble character, develop education based on science, technology, and develop learning bilingual.

The success of school work programs can also be a reference material for other implementing agencies to guarantee the quality of schools. If the quality assurance of the quality of this school is implemented widely, the quality of education nationally can be increased, not only in the quality of the 
school which makes students smart in cognitive and psychomotor ways, but from the affective it is also very much considered in the hidden moderate Islamic curriculum.

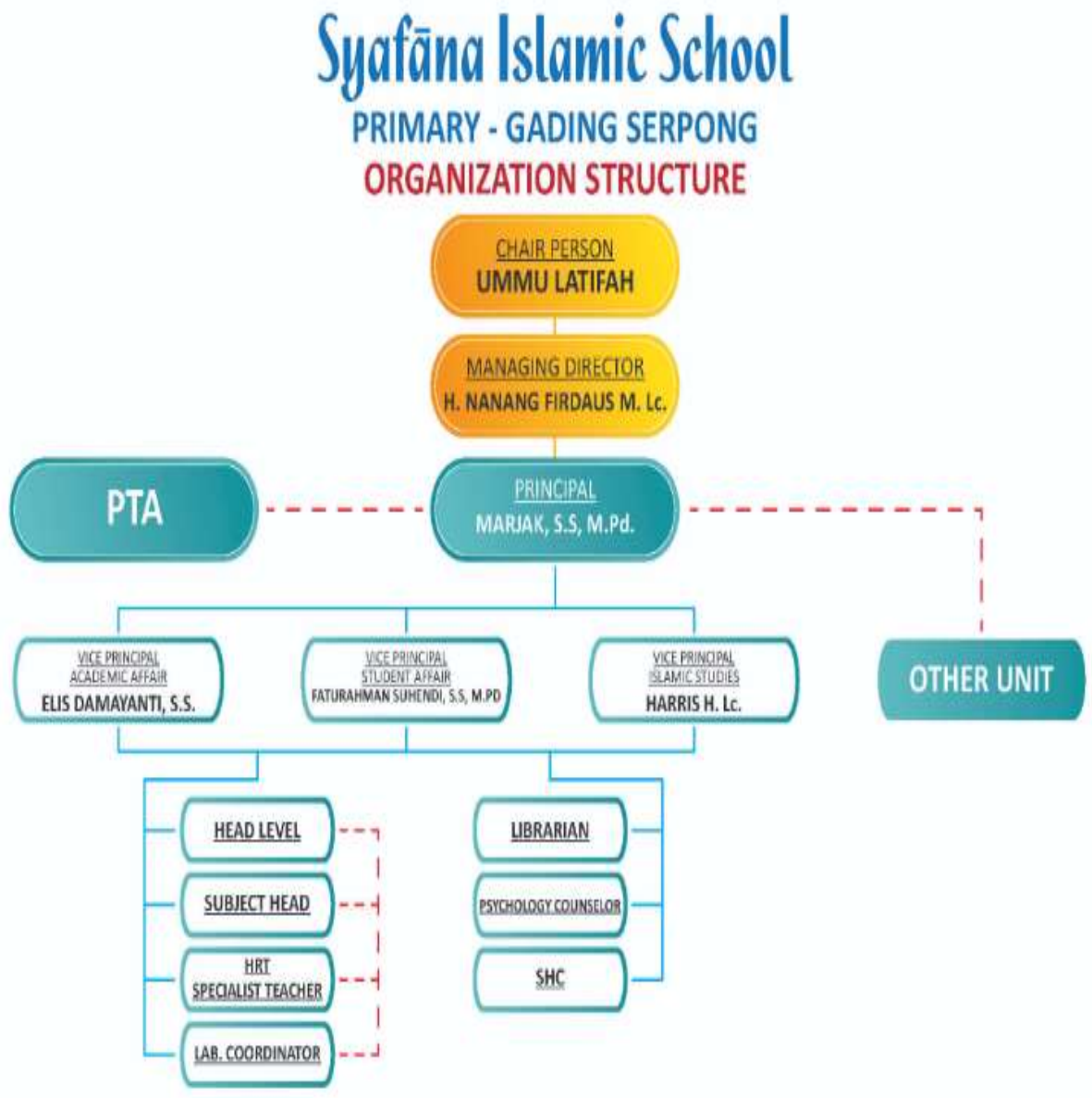

\section{a. National Curriculum}

Basically, the SD Syafana Islamic School curriculum which has a Moderate Islamic ideology is an integration or a combination of the national curriculum (K-13), the international curriculum and the Al-Azhar Cairo curriculum, without reducing the existing competencies in the 2013 curriculum instead provides additional according to the vision and mission SD Syafana Islamic School. This addition relates to the formation of graduates as moderate Muslims who of course believe and fear Allah, are knowledgeable, are responsible for the nation and state and have the ability to communicate in Arabic and English. In accordance with the applicable provisions, SD Syafana Islamic School can add or enrich the content or content according to your needs and demands.

The following is the Syafana Islamic School Elementary School Learning Program which describes the diversity of content that supports its vision and mission. 


\begin{tabular}{|c|c|c|c|c|c|c|}
\hline \multicolumn{7}{|c|}{ Table 1} \\
\hline TIME & Monday & Tuesday & Wednesday & Thursday & TIME & Fr ida y \\
\hline $\begin{array}{l}07.30- \\
07.37\end{array}$ & \multicolumn{4}{|c|}{ Tausiyah (Sydh Febri) } & $\begin{array}{c}07.30- \\
07.37\end{array}$ & $\begin{array}{c}\text { Tausiyah (Sydh } \\
\text { Febri) }\end{array}$ \\
\hline $\begin{array}{c}07.37- \\
08.20\end{array}$ & \multicolumn{4}{|c|}{ Tahfizh (Sydh Febri ) } & $\begin{array}{c}07.37- \\
08.20\end{array}$ & $\begin{array}{c}\text { Tahfizh (Sydh } \\
\text { Febri ) }\end{array}$ \\
\hline $\begin{array}{l}08.20- \\
08.55\end{array}$ & \multirow{2}{*}{$\begin{array}{c}\text { Science } \\
\text { (Ust Wawan) }\end{array}$} & \multirow{2}{*}{$\begin{array}{l}\text { English } \\
\text { (Ust } \\
\text { Wawan) }\end{array}$} & \multirow{2}{*}{$\begin{array}{c}\text { PE } \\
\text { (Coach R } \\
\text { honzie ) }\end{array}$} & \multirow{2}{*}{$\begin{array}{c}\text { Math } \\
\text { (Sydh Putri) }\end{array}$} & $\begin{array}{l}08: 20- \\
08.55\end{array}$ & \multirow{2}{*}{$\begin{array}{l}\text { Arabic (Sydh } \\
\text { Febri ) }\end{array}$} \\
\hline $\begin{array}{c}08.55- \\
09.30\end{array}$ & & & & & $\begin{array}{c}08.55- \\
09.30\end{array}$ & \\
\hline $\begin{array}{c}09.30- \\
09.50\end{array}$ & \multicolumn{4}{|c|}{ DHUHA PRAYER ( Sydh Febri \& Ust Wawan ) } & $\begin{array}{c}09.30- \\
09.50\end{array}$ & $\begin{array}{c}\text { RECESS } \\
\text { ( Ust Wawan \& } \\
\text { Sydh Febri ) }\end{array}$ \\
\hline $\begin{array}{c}09.50- \\
10.10\end{array}$ & \multicolumn{4}{|c|}{ RECESS ( Ust Wawan \& Sydh Febri ) } & $\begin{array}{c}09.50- \\
10: 10\end{array}$ & $\begin{array}{c}\text { Literacy } \\
\text { Program } \\
\text { ( Ust Wawan \& } \\
\text { Sydh Febri ) }\end{array}$ \\
\hline $\begin{array}{c}10.10- \\
10.45\end{array}$ & \multirow{2}{*}{$\begin{array}{c}\text { Al-Qur'an } \\
\text { (Sydh Febri) }\end{array}$} & \multirow{2}{*}{$\begin{array}{l}\text { Islamic } \\
\text { Studies } \\
\text { (Sydh } \\
\text { Febri ) } \\
\end{array}$} & \multirow{2}{*}{$\begin{array}{l}\text { Math } \\
\text { (Sydh } \\
\text { Putri) }\end{array}$} & $\begin{array}{l}\text { Library } \\
\text { Time }\end{array}$ & $\begin{array}{l}10.10- \\
10.45\end{array}$ & \multirow{2}{*}{$\begin{array}{c}\text { Math } \\
\text { (Sydh Putri) }\end{array}$} \\
\hline $\begin{array}{c}10.45- \\
11.20\end{array}$ & & & & \multirow{2}{*}{$\begin{array}{l}\text { Science } \\
\text { (Ust } \\
\text { Wawan) }\end{array}$} & $\begin{array}{c}10.45- \\
11.20\end{array}$ & \\
\hline $\begin{array}{c}11.20- \\
11.55\end{array}$ & $\begin{array}{c}\text { English } \\
\text { (Ust Wawan) }\end{array}$ & $\begin{array}{c}\text { Science } \\
\text { (Ust } \\
\text { Wawan) }\end{array}$ & $\begin{array}{c}\text { Science } \\
\text { (Ust Wawan) }\end{array}$ & & $\begin{array}{c}11.20- \\
11.55\end{array}$ & $\begin{array}{c}\text { Kurtilas (Ust } \\
\text { Wawan) }\end{array}$ \\
\hline $\begin{array}{c}11.55- \\
12.55\end{array}$ & \multicolumn{4}{|c|}{ DZUHUR \& LUNCH PRAYER ( Sydh Febri \& Ust Wawan) } & $\begin{array}{c}11.55- \\
12.55\end{array}$ & $\begin{array}{c}\text { FRIDAY } \\
\text { PRAYER \& } \\
\text { LUNCH } \\
\text { (Sydh Febri \& } \\
\text { Ust Wawan) } \\
\end{array}$ \\
\hline $\begin{array}{c}12.55- \\
13.30 \\
\end{array}$ & \multirow{2}{*}{$\begin{array}{l}\text { I glanced at it } \\
\text { (Ust Wawan) }\end{array}$} & \multirow{2}{*}{$\begin{array}{c}\text { Art } \\
\text { ( Ust Heru } \\
\text { ) }\end{array}$} & \multirow{2}{*}{$\begin{array}{l}\text { I glanced at it } \\
\text { (Ust Wawan) }\end{array}$} & $\begin{array}{c}\text { English ( } \\
\text { Native ) }\end{array}$ & $\begin{array}{l}12.55- \\
13.30 \\
\end{array}$ & \multirow{2}{*}{$\begin{array}{c}\text { IT } \\
\text { ( Ust Bhustomy } \\
\text { ) }\end{array}$} \\
\hline $\begin{array}{c}13.30- \\
14.05\end{array}$ & & & & \multirow{2}{*}{$\begin{array}{l}\text { English } \\
\text { (Ust } \\
\text { Wawan) }\end{array}$} & $\begin{array}{c}13.30- \\
14.05\end{array}$ & \\
\hline $\begin{array}{c}1405- \\
14.40\end{array}$ & $\begin{array}{c}\text { Arabic } \\
\text { (Sydh Febri ) }\end{array}$ & $\begin{array}{c}\text { Kurtilas } \\
\text { (Ust } \\
\text { Wawan) }\end{array}$ & $\begin{array}{c}\text { Arabic } \\
\text { (Sydh Febri) }\end{array}$ & & $\begin{array}{c}1405- \\
14.40\end{array}$ & $\begin{array}{c}\text { Islamic Studies } \\
\text { (Sydh Febri ) }\end{array}$ \\
\hline $\begin{array}{c}14.40- \\
15.00\end{array}$ & \multicolumn{4}{|c|}{ Muroja'ah ( Sydh Febri) } & $\begin{array}{c}14.40- \\
15.00\end{array}$ & $\begin{array}{l}\text { Muroja'ah ( } \\
\text { Sydh Febri) }\end{array}$ \\
\hline
\end{tabular}

This is also an example of moderate Islam in the elementary school curriculum Syafana Islamic School who download combine three curriculum including the National Curriculum, International curriculum and curriculum of Al-Azhar.

Moderate Islamic learning load curriculum in elementary Syafana Islamic School 's esuai with the burden of learning the curriculum in 2013 ( Minister of education number 67 in 2013 ), the regulation of primary school learning load is determined as follows:

b. Character education and school culture

Students who have graduated from Syafana Islamic School are expected to have mastered and possessed the following abilities: (1) Religion , (2) Science, (3) Arts and sports , (4) Language fields .

c. Graduation quality improvement programs

That Islamic education at SD Syafana Islamic School is very concerned because with learning, especially religion will shape the mindset of students, Islamic education at SD Syafana Islamic School uses the original Al-Azhar book which we know how the thoughts of Al-Azhar alumni who have already moderate by using fiqih mazahibul arbaah, here emphasizes more on practice in matters of worship and in the content of the material teaches students to know which is ushul and which is furu, so that students become outputs who have flexible thoughts in dealing with the differences that are rife in Indonesia .

\section{Implementation of moderate Islamic curriculum activities}

The implementation as described in the previous section (point 1) above is implemented in the form of 
teaching and learning activities. Teaching and learning activities (KBM) are led and guided by the teacher, using learning methods that are in accordance with the learning objectives, the conditions of students and the environment as well as the specificities of learning materials. Existing facilities and infrastructure are used optimally so that students achieve predetermined competencies. Scheduled teaching and learning activities include: Tausiah and motivation; Tahfidz; learn ; prayer duha congregation ; snack time ; learn ; noon prayer ; lunch together ; learn ; and murojaah. Teaching and learning activities are integrated between cognitive, affective and psychomotor.

\section{Curriculum evaluation}

The evaluation in question is an assessment of learning outcomes which is also part of the curriculum. The evaluation that is applied includes: formative evaluation, midtest, final or summative test and practical test or skills test. Process and student learning outcomes are also evaluated. The evaluation results are contained in two types of report cards, namely; report cards Curriculum 2013 and SD Syafana School report cards.

\section{The role of teachers at SD Syafana Islamic School.}

In supporting learning to realize the vision and mission of SD Syafanah Islammic School, teachers are prepared through training and habituation to strengthen their competence and professionalism, both classroom teachers, homeroom teachers and administrators or administration, which in essence are:

First, the duties of teachers in the professional field include educating, teaching and training. Educating means continuing and developing the value of life, teaching means continuing and developing science and technology. Meanwhile, training means developing student skills ;

Second, the teacher's duty in the field of humanity is to make himself a parent. He must be able to attract the sympathy of students, if he does not look attractive, he will fail to instill the value of his teaching; and

Third, the teacher's duty in the social field. Teachers are noble figures and are glorified by many people, the presence of teachers in the midst of human life is very important, without human teachers there will be no culture, norms, religion.

\section{Implementation of the Moderate Islamic curriculum at SD Syafana Islamic School, especially in hidden curriculum}

\section{Planning for hidden curriculum in SD Syafana Islamic School}

The hidden curriculum does not appear in an educational institution, because it is not written in the curriculum document. However, it is precisely in the curriculum that the power is hidden to be able to print the personality and ideology of students. Therefore, moderate values such as behaving normally (tawassut ) in religion, being tolerant of differences of opinion, avoiding violence, prioritizing dialogue, accommodating modern concepts that contain substantially maslahat, thinking rationally based on revelation, interpreting the text contextually, and using ijtihad in interpreting what is not contained in the Koran or the Sunnah, having a harmonious and cooperative attitude with different religious groups, can be internalized in the installation process of moderate Islamic ideology. These values need to be installed in a hidden curriculum.

\section{Implementation of hidden curriculum at SD Syafana Islamic School}

\section{a. Implementation of hidden curriculum in teaching and learning activities (KBM) includes :}

1) Yell yells before class

To instill togetherness and cohesiveness of students and instill the enthusiasm that exists every day From the social side, namely:

a) There is a close interaction between teachers and students

b) The existence of familiarity between students with each other sehingg a danya interaction more intense each other

c) the existence of these activities will generate a sense of empathy or concern for others

2) Greeting $5 \mathrm{~S}$ (smile, greeting, greeting, courtesy, courtesy)

The purpose of this activity is so that students can respect people who are older than them in general and their teachers in particular and can respect their peers. The benefit is the benefit of this activity, which is to provide solutions in establishing friendly interactions and upholding courtesy

3) Motivation and tausiah

The teacher provides motivation based on the Al-Quran and Hadith every morning, motivation is a change in energy in a person's (personal) self, which is marked by the emergence of feelings and reactions to achieve a goal. The task of a teacher is not only to organize teaching, research, develop activities., and manage an educational institution, especially students. The teacher is also responsible for generating students' motivation to learn.

Tahfidh that can be extracted from the process of memorizing the Quran itself, from the process or how to memorize the Koran which now can be learned in a fun way, to the benefit of learning and memorizing the Koran itself. The benefits of memorizing the Koran include: Training 
power of concentration, stimulating the brain and the level of intelligence, avoiding senility , fostering discipline, deeper understanding of the Quran, virtue of the world and the hereafter.

4) Praying together every activity

For religious cultivation for students, that what we do must begin with praying that everything goes well and is blessed by Allah, and with that prayer increases the faith of the students. 5) Sodaqah

To instill a sense of caring for students in humans, sodaqah teaches children to like to give, because giving is more noble than asking and teaching children to continue to do good that aims at Allah.

6) Murojaah

Instilling children to be responsible for memorizing and also strengthening so they don't forget to memorize it not only increases the intelligence of the brain in memorizing

7) Read Asmaul Husna

8) Duha prayer

The benefits of Duha prayer are a vehicle for our hope of Allah's grace and blessings. throughout the day, whether in the form of physical or material favors. As the Prophet Muhammad SAW said, "Allah said, 'O son of Adam, don't you ever be lazy to pray the four rak'ahs in the morning, namely the Dhuha prayer, I will surely fulfill your needs until the afternoon."' (Al-Hakim and At-Tabrani), more than that, the moment of Dhuha prayer is a time when we replenish our new spirit of life. We hope that the day we are going through will be a better day than yesterday. This is where the space we plant life optimism. We don't live this life alone.

9) Zuhr prayer \& Asr prayer in congregation

Prayers in congregation are part of coaching students who are included in character education. Even schools will be able to produce students who are not only smart in brain but also intelligent in character. Therefore, let us practice congregational prayer in our daily life. By praying in congregation there is a high sense of togetherness and we will also gain Robbi's divine grace .

10) Familiarity of students during kbm

\section{b. Outside teaching and learning activities (KBM)}

The implementation of the hidden curriculum outside the classroom is contained in the Syafana Islamic School SD Work Program plan for 2019-2020 (before the Covid-19 pandemic).

These activities which have been regularly carried out and will continue to be carried out include: (1) entrepreneur day at SD Syafana Islamic School ; (2) Assambly Events ; (3) Islamic Mahrajan ; (4) culture day event ; (5) flag ceremony; (6) independence day events; (7) commemoration of mauled Prophet Muhammad SAW and Islamic holidays and so forth.

c. School environment

Order and cleanliness of the school environment. Teachers, students and school employees participate actively in maintaining the school environment so that order, cleanliness and everything is healthy, which plays an important role in the success of the learning and teaching process, both outside the classroom and the school environment itself.

\section{Evaluation of Hidden Curriculum at SD Syafana Islamic School}

$\mathrm{B}$ uku the observation that they have that contain Islamic development carried out during the school day and continuing at home. Every activity, teachers and parents give initials so that these developments are continuously monitored. Every day the class teacher always checks the Islamic development monitoring book. There are activities that do require a coordinator as the person in charge of the assessment .

The second form of evaluation is that the assessment is carried out in a curriculum report, where the class teacher gives an assessment through a written description of the student's attitude in the report card, the assessment is carried out by the teacher by seeing every day how the student is good or bad, the teacher will provide an assessment of daily activities -That day. according to the author, this can be used as a form of evaluation to see a written teacher assessment. Parents also have an important role in it so that parents know in detail what kind of attitude their children have been doing at school.

The third form of evaluation of the behavior of students is also carried out by all teachers and homeroom teachers. If teachers see the violations committed by students in the type of minor violations, the teacher has the right to reprimand and follow up on them. Verbal warnings, written warnings, summons from parents / guardians, suspension, returned to parents / guardians. Violations that occur can be committed by students inside and outside of school. In accordance with the rules of SD Syafana Islamic School.

\section{Out Put the Hidden Curriculum SD Syafana Islamic School}

The concept of hidden curriculum is seen in activities that lead to values that can shape the character of students. The habituation activities carried out by SD Syafana Islamic School which are 
described in the previous social system can certainly instill moderate Islamic values which have tawazun, tawasut, tasamuh, fair and musawah characteristics which are the goals of SD Syafana Islamic School.

The attitude that is expected in implementing the hidden curriculum is of course positive and religious attitudes because many Islamic values have been applied at SD Syafana Islamic School. In the hidden description, the curriculum gives more value to how important it is to be applied in everyday life. The school also hopes that there will be an implementation that will continue to be carried out continuously in everyday life.

\section{The Effectiveness of Moderate Islamic Curriculum at SD Syafana Islamic School}

In teaching and learning activities that incorporate the National Education curriculum such as curriculum lessons 2013, Al-Azhar curriculum such as Arabic, Islamic religious education, tahfidz and AlQuran and international curricula such as math, English and science lessons which go hand in hand to make students have integration science coupled with the role of teachers who greatly influence in supporting school goals even the lessons that have been taught are influential in providing values that are in accordance with the Al-Quran and the hadiths of students so as to give birth to a good generation too.

\section{E. Discussion of Research Results}

Based on the data exposure and the results of the researchers described in the previous chapter, in this chapter the researcher will discuss and discuss more deeply into a new concept based on the results of research in the field. As for the discussion in this chapter, namely

1. Moderate Islamic curriculum at SD Syafana Islamic School

2. Implementation of the moderate Islamic curriculum, especially the Hidden Curriculum at SD Syafana Islamic School

3. The effectiveness of the moderate Islamic curriculum at SD Syafana Islamic School.

a. Islamic Curriculum at SD Syafana Islamic School

Curriculum implementation is an operational curriculum concept that is still written into actual in the form of learning activities. In shaping the Al-Azhar curriculum in moderate Islamic ideology at SD Syafana Islamic School it is necessary .

1) Planning

Planning plays an important role in optimizing the results of a curriculum development process. In the learning process, there are things that must be prepared for administrative matters. Before carrying out learning in class, there are several things that must be prepared by a teacher. The basic thing is the preparation in the learning process such as learning administration such as annual programs, semester programs, syllabus, lesson plans, and evaluation.

2) Implementation

a) Teaching and learning activities in the classroom

b) Teaching and learning activities outside the classroom

3) Curriculum evaluation

Curriculum evaluation at SD Syafana Islamic School uses national assessment standards looking at the cognitive, affective and psychomotor students of the study taken from the assessment:
a) Worksheet test
b) Formal test
c) Midtest
d) Finaltest
e) Practical test

According to researchers, in carrying out the moderate Islamic curriculum, especially in the written curriculum, it has advantages and disadvantages. The advantages of the written curriculum include :

1) Curriculum excellence

a) Increase students in broad insights including world science and in the afterlife.

b) The mindset of students becomes flexible in religious matters

c) $\mathrm{P}$ endekatan contextual understanding Islam

d) Non-violent ideology in spreading Islam

e) Competitive

f) There is assessment from all aspects. The determination of value for students is not only obtained from values but from the values of politeness, religion, practice, attitudes and others.

g) Many competencies are needed according to development such as character education, active learning methodology, balance of soft skills and hard kill and entrepreneurship.

h) Emphasizes practice in every lesson 
i) Learning with a fast method so that students quickly understand

j) Supervision of student character

k) Assessment standards lead to competency-based assessments such as attitude, skills and knowledge proportionately.

1) It is hoped that teacher creativity will increase

m) P embelajaran student-centered and contextual with a more varied learning methods

n) Assessment includes aspects of cognitive, affective, psychomotor in proportion

2) Weaknesses of the Moderate Islamic curriculum

a) Teachers have not mastered the assessment, especially the 2013 curriculum assessment

b) The learning load of students and teachers is too heavy, so that the learning time at school is too long.

c) Increase the workload of teachers.

d) There are too many materials that must be mastered by students so that not every material can be conveyed properly .

e) Learning tahfidz is not optimal because there are too many memorizing and also activities so that memorizing the Al-Quran is not too optimal.

f) Learning Islamic religious education that uses Arabic is almost not optimal for grades 4 and 6 because some students experience difficulties.

- Here the researcher will provide a framework for the Moderate Islamic curriculum at SD Syafana Islamic School.

Tabel 2

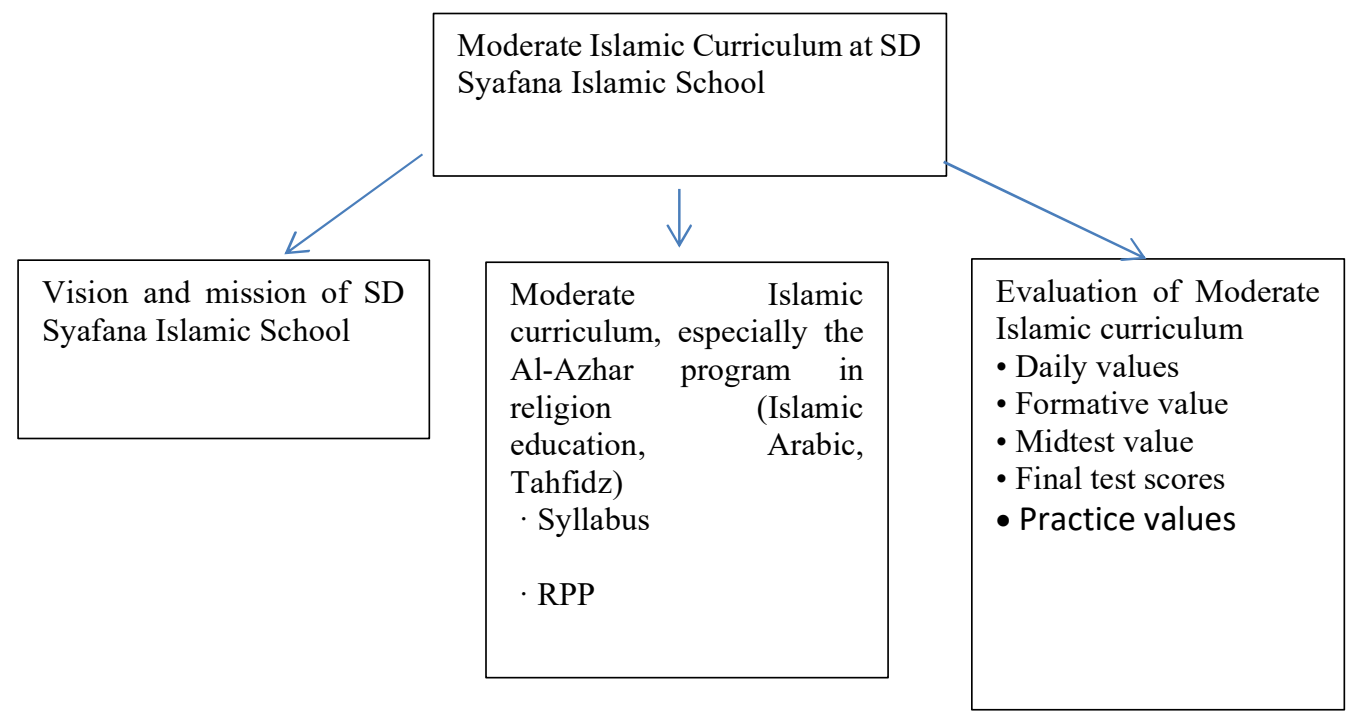

b. Implementation of the modern Islamic curriculum, especially the Hidden Curriculum at SD Syafana Islamic School

SD Syafana Islamic School implements Hidden Curriculum activities with various programs with the expected output goals and objectives, namely Moderate Islam . In planning the hidden curriculum of SD Syafana Islamic School, the vision and mission is a tool to achieve the Hidden Curriculum . Vision and mission are the main benchmarks in achieving goals. Through the establishment of a clear vision and mission, prioritizing the strengthening of religion, so that it has Islamic nuances and gives trust to the wider community.

In implementing the Hidden Curriculum the researcher looks at the aspects of the Hidden Curriculum in terms of organizational systems, social systems and cultural systems. In this case the school explains that the organizational system in the school is under the leadership of the school principal, the curriculum section and the research section. So that the connection with the application of Hidden Curriculum is part of the curriculum structure which explains that the school has a curriculum of its own that has designed the school as Local content (distinctiveness SD Syafana Islamic School), selfdevelopment and activities of habituation In the social system of the school is strengthening with their habituation course have an impact on students who are carried out regularly, which has a long-term effect in daily life. Teachers have an important role in instilling the values that are carried out in schools. These activities will make grow empathy or concern for others. 
Tabel 3

Hidden Curriculum Islam Moderat di SD Syafana Islamic School

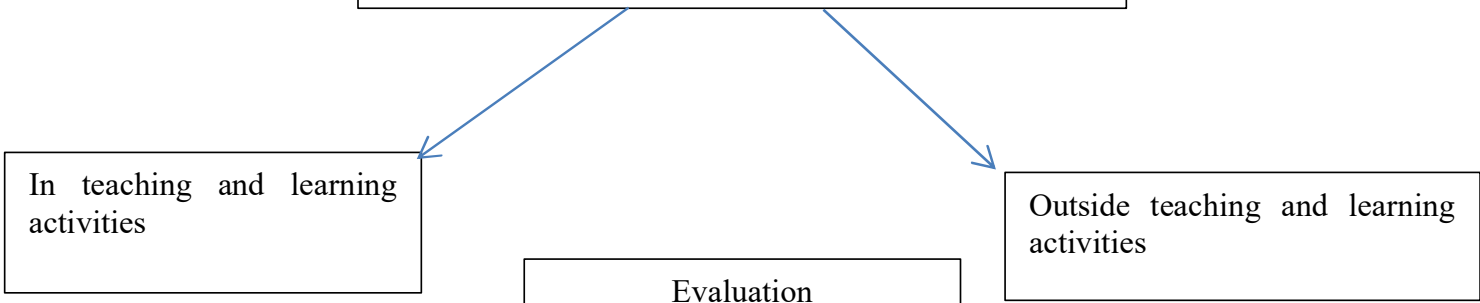

Evaluation

1. The advantages of hidden curriculum during teaching and learning activities (kbm)

The advantages of the hidden curriculum during learning are that it makes students understand how to deal with problems because every problem that participants face in the classroom is always discussed together as learning, not only motivation - the motivation conveyed by the teacher becomes the mindset of students so that they continue to be good human beings, Praying activities, smiling greetings that are accustomed to every day make students' character attitudes, congregational prayer is also carried out because it makes human students who are balanced in knowledge and morals Weaknesses of hidden curriculum during teaching and learning activities (kbm)

The weakness of the hidden curriculum during learning activities at SD Syafana is the lack of preparation for holding events due to the overcrowding of programs at SD Syafana so that an activity is not complete.

2. The advantages of hidden curriculum in non teaching and learning activities (kbm)

The advantages of hidden curriculum when teaching and learning activities are many because there are many activities that support the vision and mission of the school such as increasing students' religious values, student social values and student nationalist values, not only that, with these activities emphasizing student confidence and courage in presenting ideas. creative and innovative students, even a lot of student achievement in school and outside school because they have been trained from school non-teaching and learning activities.

3. Weaknesses of hidden curriculum non teaching and learning activities (kbm)

The weakness of the non-KBM hidden curriculum is that there are too many programs which make the implementation of activities sometimes run less optimally and even impact on teaching and learning activities in class where teachers are left with material that must be explained in accordance with the syllabus and for other schools it may be non-teaching and learning activities programs. This requires huge funds in realizing the non-KBM hidden curriculum .

\section{F. Conclusion}

Base on data findings and discussion in Chapter 4, it may take some research study conclusions. The general conclusion of the research is that SD School Syafana Islamic carries out various program activities to shape the character of students according to the school ideology, namely moderate Islam . Specific conclusions include:

1. SD Syafana Islamic School designs moderate Islamic curriculum programs such as the National curriculum, the International curriculum, the Al-Azhar curriculum for character building of students in accordance with the school ideology, namely moderate Islam along with the implementation and evaluation of the moderate Islamic curriculum, especially the Al-Azhar curriculum, because it looks at the material- school religious material. And the Moderate Islamic curriculum greatly affects the wasathiyah data in the thinking patterns of students so that students can think flexibility according to the Al-Quran and hadiths and tolerance so that students are able to be wise in dealing with differences.

2. SD Syafana Islamic School designed a hidden curriculum in support of the curriculum that was designed by schools such as the hidden curriculum when teaching and learning in class and hidden curriculum outside teaching and learning activities and it went well even though there were some constraints in terms of time and it was quite successful in character building of students, especially in leadership, intellectuality and creativity so that students can face changes and challenges. The practice of hidden curriculum at SD Syafana Islamic School has succeeded in shaping the character of students, namely SD Syafana Islamic School including religious values, social values and nationalist values with attitudes of flexibility, tolerance, self-discipline, independence and care for others , progress, rational thinking, upholding peace, 
and thinking rationally with the arguments of the Koran and hadiths, it was proven when researchers interviewed students at SD Syafana Islamic School.

3. Character building through the curriculum and hidden curriculum at SD Syafana Islamic School has not been fully successful in maximizing these activities, for example in the curriculum

a. Learning tahfidz is not running optimally because there are too many memorizing activities and so many activities so that students often do not remember the previous memorization, even not all memorized according to the target.

b. Learning Islam, especially in grades 4 and 6, did not run optimally due to the constraints of the Arabic language, because the introduction and books used Arabic. With the existing application in the hidden curriculum aspects, it can shape the character of students. This can be seen from the formation of the character of students while they are in school activities.

This research also concludes that in order to realize the school's vision and mission, namely moderate Islamic ideology, it is necessary to combine the written curriculum with the hidden curriculum so that it becomes an integrated part. Moderate Islamic ideology which is used as a manhaj for the Syafana school to design a written curriculum in providing integrated data such as religion and general science.Therefore, there must be supplements to optimize the role of education on the character of students, namely the hidden curriculum in building balance.

\section{References}

Abdullah, M. Yatimin. Studi Akhlak dalam Perspektif Al-Qur'an, Jakarta: Amzah, 2007.

Al-Syaibany, Omar Muhammad Al- Toumy. Falsafah Pendidikan Islam, terj.Hassan Langgulung, Jakarta: Bulan Bintang, 1997.

Amalee, Irfan. Islam itu Ramah bukan marah, Bandung:PT Mizan Publika, cet.1, Juli 2017.

Arhanuddin Salim, Yunus. "Eksistensi Modernisasi Islam dalam Kurikulum Pembelajaran PAI di SMA”, dalam jurnal Al-Tadzkiyyah: Jurnal Pendidikan Islam, Volume 9, No. 22018.

Arifin, Zainal. Konsep dan Model Pengembangan Kurikulum, Bandung: Remaja Rosdakaraya.

Arifudin, Iis. "Integrasi Sains dan Agama serta Implikasinya terhadap Pendidikan Islam : Fakultas Tarbiyah Keguruan UIN Sunan Gunung Jati Bandung,” dalam jurnal Edukasia Islamika, Vol 1. No. 1 Desember 2016.

Beauchamp, George. Curriculum Theory: Third Edition. (Illinois: The Kagg Press, 1975) dalam Zainal Arifin, Konsep dan Model Pengembangan Kurikulum.

Baidlowi, Masduki. MUI dan Visi islam wasatiyah, majalah mimbar ulama, Agustus 2015.

Bubacher, Jhon.S. Modern Philosophy of Education, New Jersey, Engelwood Company, 1962, hal.238, dalam Rino Rusdi, Kurikulum Perencanaan, Implementasi, Evaluasi, Inovasi dan Riset.

Buseri, Kamrani, Islam Wasathiyah dalam Perspektif Pendidikan: Pengajar Ilmu Pendidikan Islam Filsafat Ilmu dan Manajemen Pendidikan Islam Pascasarjana IAIN Antasari, Rakerda/Sarasehan Ulama se Kalimantan Selatan Di Banjarmasin, Tanggal 28 Desember 2015.

Cawista, The Hidden Curiculum, Yogyakarta: Leutikaprio,2013.

Dakir, Perencanaan dan Pengembangan Kurikulum, Jakarta: Rineka Cipta, 2004.

Esha, M zainuddin Muhammad Enam. Islam Moderat Kosepsi Intepretasi dan Aksi, t.tp: UIN Malik press, Februari 2016.

Fitriani, Elly. "Implementasi Hidden Curriculum dalam Pembentukan Karakter Religius Peserta Didik" , studi Multi Situs MAN Model dan SMA Muhammadiyah Al-Amin Sorong), Tesis, Universitas Islam Negri Maulana Malik Ibrahim Malang, 2017.

Futaqi, Sauqi. "kontruksi Moderasi Islam (Wasathiyah) dalam Kurikulum Pendidikan Islam”, dalam jurnal second proceedings annual conference for muslim scholar kopertais wilayah IV Surabaya, 21 - 22 April, 2018.

Indrasutanto, Tjondro. "Kurikulum Berbasis Kompetensi dan Pendidikan Kecakapan Hidup (Life Skill Education", dalam jurnal Magister Scientiae - ISSN: 0852-078X 1 Edisi No.23 - Maret 2008

Jalaluddin dan Usman Said, Filsafat Pendidikan Islam, Jakarta: Raja Grafindo Persada, 1996, cet 2.

Jenuri. "Tangtangan dan Strategi Pendidikan Islam dalam Mewujudkan Siswa dan Sekolah Berkualitas," dalam penelitian Dosen UPI Kampus Cibiru.

Kamba, Nursamad Konstruksi Islam Moderat Menguak Prinsip Rasionalis, Humanis, dan Universal Islam, Yogyakarta: Aura Pustaka, cet pertama, Mei 2012.

Kurinasih, Imas dan Berlin Sani. Implementasi Kurikulum 2013 Konsep dan Penerapannya. Surabaya: Kata Pena, 2014.

Kurniawan, Syamsul. Pendidikan Karakter: Konsepsi \& Implementasi Secara Terpadu di Lingkungan Keluarga, Sekolah, Perguruan Tinggi dan Masyarakat...

Lestari, Gina. "Bhinnekha Tunggal Ika: Khasanah Multikultural Indonesia di Tengah Kehidupan Sara”, Jogja: Program Studi Ketahanan Nasional Universitas Gadjah Mada, dalam Jurnal Pendidikan Pancasila dan Kewarganegaraan, Th. 28, Nomor 1, Pebruari 2015. 
Lussy. Pengembangan Pembelajaran Pendidikan Agama Islam Melalui Metode Pendidikan terbuka di SDIT Bina Anak Sholeh II, Yogyakarta: Tarbiyah IAIN Sunan Kalijaga, 2004.

M. Hanafi, Muchlis. Moderasi Islam: Menangkal Radikalisasi Berbasis Agama, Jakarta: Ikatan Alumni al-Azhar dan Pusat Studi Al-Qur'an, 2013, hal. 3-4.

Madjid, Nurcholish. Islam Doktrin dan Peradaban, Jakarta: Paramadina, 2008.

Madjid, Nurcholish. Masyarakat Religius Membumikan Nilai-Nilai Islam dalam Kehidupan Masyarakat,Jakarta : Paramadina, 2000.

Majid, Abdul dan Dian Andayani. Pendidikan Agama Islam Berbasis Kompetensi. Bandung: PT Remaja Rosdakarya.

Majid, Abdul dan Dian Andayani. Pendidikan Agama Islam Berbasis Kompetensi. Bandung: PT Remaja, Rosdakarya.2006.

Mashadi, Imron, reformasi pendidikan agama islam di era multikultural, Jakarta: balai penelitian dan pengembangan agama Jakarta, September, 2009.

Miftahuddi. " Islam Moderat Konteks Indonesia dalam Perspektif Historis", dalam jurnal MOZAIK, Volume V Nomor 1, Januari 2010.

Mualimin, Bukan Azhari Jika Tidak Moderat, Kairo, Jumat 6 April 2018 dalam https://mualliminenamtahun.net/berita/bukan-azhari-jika-tidak-moderat/

Mulyana, Deddy. Metodologi Penelitian Kualitatif, Bandung: PT Remaja Rosdakarya.

Nasution, Pengembangan Kurikulum, Bandung:PT.Citra Aditya Bakti,1993.

Nata, Abuddin, Metodologi Studi Islam, Jakarta: PT. Raja Grafindo Persada, 2010.

$\mathrm{Nu}$ Oline, "Indonesia Diharapkan Jadi Barometer Islam Moderat" dalam http://www.nu.or.id/, Diakses pada 29 Maret 2015.

Nur, Afrizal dan Mukhlis Lubis. "Konsep Wasathiyah dalam A-Quran; Studi Komparatif Antara Tafsir Al-Tahrir wa At-Tanwir dan Aisar At-Tafsir," dalam jurnal An-Nur, Vol. 4 No. 2, 2015.

Nuriyanto, Liliam Kadarin. "Model Kurikulum Pendidikan Agama Islam di SD IT AL-Anwar dan Firdaus Mojokerto", Semarang: Balai Penelitian dan Pengembangan Agama, dalam jurnal Edukasi, Vol. 12, No1, Januari-April 2014.

Al-Qardhawi, Yusuf. al-Kalimat fi al-Wasathiyah al-Islamiyah wa Ma'alimaha Cairo: Dar al-Shuruq, 2011.

Al-Qhardawi, Yusuf. Islam Jalan Tengah, Bandung: pt Mizan Pustaka,Oktober 2017.

Rahayu, Sri. "Hidden Curriculum (Kurikulum Tersembunyi )," dalam http://Srirahayustkip.blogspot.co.id, Diakses 10 maret 2017.

Rahman, Fazlur. Islam dan Modernitas, Bandung:Pustaka, cet.1, 1985 M, 